\title{
NEW PHREODRILIDAE (ANNELIDA: CLITELLATA) FROM TASMANIAN ESTUARIES
}

\author{
by Adrian M. Pinder and Christer Erséus
}

(with one text-figure)

Pinder, A.M. \& Erséus, C., 2000: (31:xii): New Phreodrilidae (Annelida: Clitellata) from Tasmanian estuaries. Pap. Proc. R. Soc. Tasm. 134: 29-33. ISSN 0080-4703. Department of Conservation and Land Management, PO Box 51, Wanneroo, WA, Australia 6946 (AMP); Department of Invertebrate Zoology, Swedish Museum of Natural History, Box 50007, SE-104 05, Stockholm, Sweden (CE).

A new species of Phreodrilidae from Macquarie Harbour, Tasmania is described. Astacopsidrilus ostiensis sp. nov. is unique in possessing the combination of long, tightly folded atria, modified spermathecal chaetae and ventral chaetae that are almost simple pointed. These are the first phreodrilids to be recorded from estuarine or intertidal habitats, other than two species collected from beaches, on Subantarctic Campbell Island, for which the habitat data are ambiguous. The existence of other Phreodrilidae from Tasmanian estuaries, of which we do not have sufficient material for description, is noted.

Key Words: Clitellata, Phreodrilidae, estuaries, Tasmania, new species.

\section{INTRODUCTION}

In recent decades, hundreds of new oligochaetes in the families Tubificidae and Enchytraeidae have been described from marine and estuarine environments in Australia and elsewhere (e.g. Jamieson 1977, Erséus 1981, 1990a,b, 1993, 1997a,b, Erséus \& Jamieson 1981, Coates 1990, Healy \& Coates 1997), exceeding the number of species of these families from inland waters. By contrast, of the 45 described species of Phreodrilidae and others awaiting description in the first author's collection, almost all appear to be restricted to inland freshwater habitats such as streams and lakes (Martin \& Brinkhurst 1994, Giani et al. 1995, Martin \& Giani 1995, Pinder \& Brinkhurst 1997).

Of the phreodrilids, the only record of Insulodrilus litoralis (Michaelsen 1924) is of the type specimens which were collected at Perserverence Harbour, Subantarctic Campbell Island, from under a rock on the beach at ebb-tide. While this may be a marine littoral species there is no information about salinity at the type locality. Astacopsidrilus campbellianus (Benham 1909) was also collected on a Campbell Island beach, but near the outlet of a freshwater stream and the species is common in freshwater streams of Macquarie Island, $900 \mathrm{~km}$ west of Campbell Island (Marchant \& Lillywhite 1994). Finally, the type locality of Antarctodrilus niger (Beddard 1894) is given as Port Stanley, Falkland Island, by its original author, but Michaelsen (1900) expanded on this, giving the locality as "zwischen Algen in einem langsam fliessenden Bach" (among algae in a slow flowing brook). All other phreodrilids identified as $A$. niger (or its synonyms) are from inland streams and rivers (Beddard 1894, Goddard \& Malan 1913, Brinkhurst $1966,1982)$.

The new species and other, unnamed, material described in this paper were collected from brackish reaches of estuaries in Tasmania. These were part of a collection of oligochaetes obtained during an extensive biological study of Tasmanian estuaries (Edgar et al. 1998), which was placed at the second author's disposal.

\section{MATERIALS AND METHODS}

The material used in this study was collected by Neville Barrett (Tasmanian Aquaculture and Fisheries Institute) and kindly forwarded to us by Graham Edgar (University of Tasmania). The specimens were fixed in formalin, and subsequently transferred to $80 \%$ ethyl alcohol. Some worms were stained in alcoholic paracarmine and mounted whole in Canada balsam, a few others were serially sectioned, mounted and stained in Mayer's haematoxylin and eosin. The type specimens of Astacopsidrilus ostiensis sp. nov, are deposited in the Queen Victoria Museum (QVM), Launceston, Tasmania, and the Western Australian Museum (WAM).

\section{SYSTEMATICS}

\section{Astacopsidrilus Goddard, 1909}

Astacopsidrilus Goddard Proc. Linn. Soc. NSW 33: 769, figs 1-17 (1909).-Brinkhurst Can. J. Zool. 69: 2040 (1991). -Pinder \& Brinkhurst Invert. Tax. 11:496 (1997).-Giani et al. Can. J. Zool. 73: 2375 (1995) - Hesperodrilus Beddard Trans. R. Soc. Edin. 36: 273 (1891) (in part).-Michaelsen Vidensk. Medd. Dan. Naturhist. Foren. 75: 208 (1924). -Stephenson THE OLIGOCHAETA, Oxford University Press: 756 (1930) - Phreodrilus (Astacopsidrilus) Beddard Trans. R. Soc. Edin. 36: 273 (1891),-Brinkhurst J. Zool. 147: 381 (1965).

\section{Diagnosis}

Plesiopore female ducts (ducts leading to pores on the first segment after the ovaries) leading to pores within ventral spermathecal vestibulae. Spermathecal vestibulae deep and muscular with muscular connections to the dorsal body wall. Well-developed pendant penes present. 

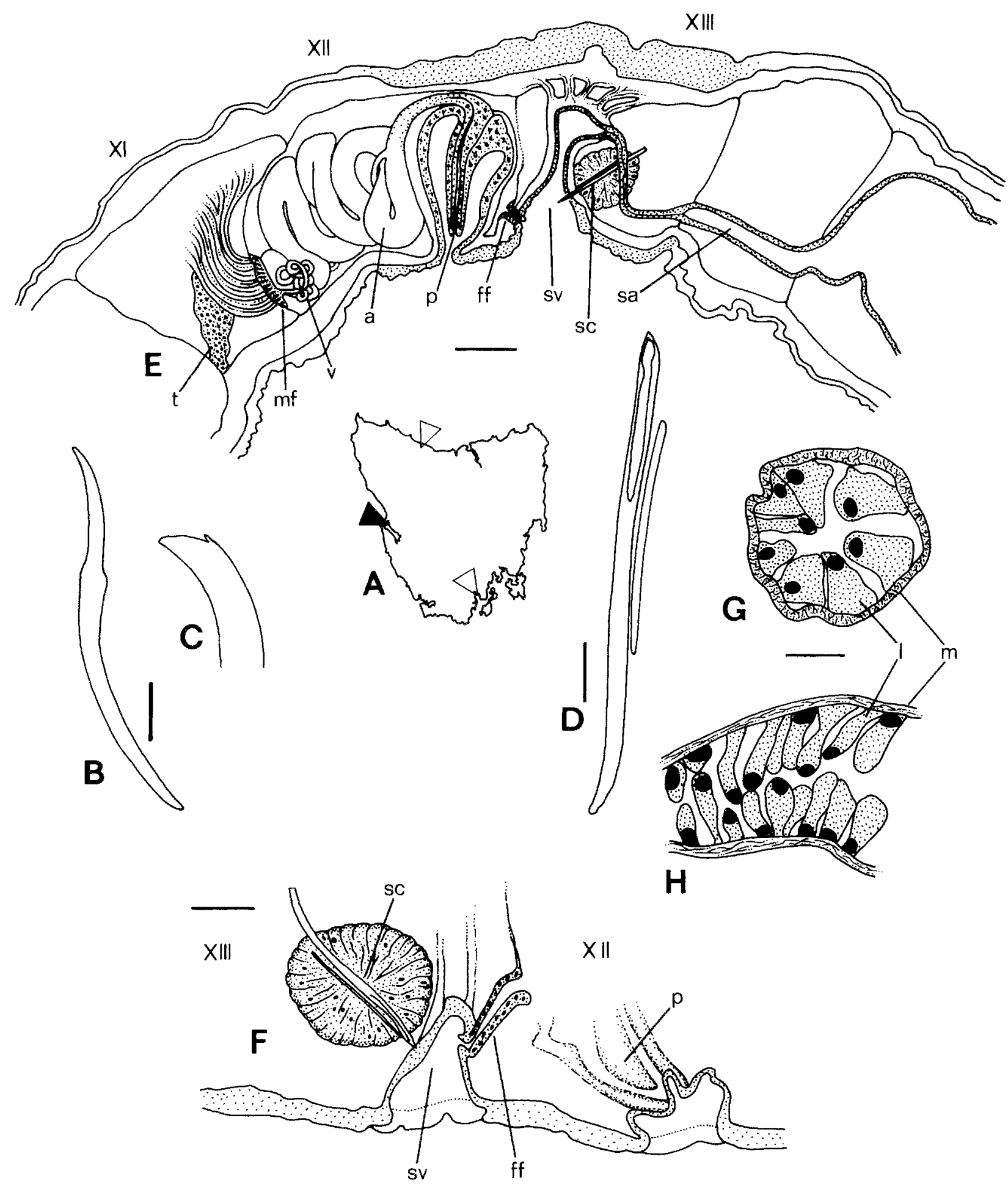

FIG. 1 - Astacopsidrilus ostiensis sp. nov. (A) Map of Tasmania showing the type locality of A. ostiensis (filled arrow head) and location of estuaries with other phreodrilids (open arrow heads); (B) Typical ventral chaeta; (C) Tip of ventral chaeta showing rudimentary upper tooth; (D) Spermathecal chaetae; (E) Longitudinal view of genital segments, reconstructed from sectioned holotype; $(F)$ Ventro-lateral view of genital pores drawn using drawing tube from whole-mounted paratype QVM 14:3866; $(G)$ Transverse section of atrium from holotype; (H) Longitudinal section of atrium from holotype. Legend: a-atrium; ff-female funnel; $l$-lining tissue; $m$ - muscle; $m \tilde{f}$-male funnel; $p$ - penis; $t$-testes; $v$-vas deferens; sa-spermathecal ampulla; sc-spermathecal chaetae; sv-spermathecal vestibule. Scales: $B, D, G$ and H, bar $=15 \mu m ; E$, bar $=100 \mu m ; F, b a r=40 \mu m$. 


\section{Astacopsidrilus ostiensis sp. nov. (fig. 1)}

\section{Specimens examined}

Holotype: QVM 14:3865. Swan Bay, Macquarie Harbour, west coast of Tasmania, $41^{\circ} 12.384^{\prime} \mathrm{S} 145^{\circ} 16.207^{\prime} \mathrm{E}$ (fig. 1A), 23 June 1996, longitudinally sectioned specimen on two slides with posterior part mounted separately on a third slide. Paratypes: QVM 14: 3866 to 3877 and WAM V 41-40 to 41-42. Type locality and date, three longitudinally sectioned specimens with posterior parts mounted separately, eight whole-mounted specimens, and several mature and immature ones in alcohol.

\section{Etymology}

From the Latin os (of the mouth, including river; as in Ostia, the harbour of Rome at the mouth of the Tiber), referring to the estuarine type locality.

\section{Description}

Length of preserved slide mounted worms up to $11.5 \mathrm{~mm}$, width up to $0.5 \mathrm{~mm}$ just anterior to clitellum, body constricted at clitellum. Number of segments 60-75. Clitellum covering posterior half of XII and all of XIII, more developed dorsally than ventrally.

Ventral chaetae two per bundle from segment II, 75$90 \mu \mathrm{m}$ long, shortest in first few segments, both chaetae of a pair appearing simple pointed (fig. 1B) but many with a rudimentary upper tooth (fig. 1C). Dorsal chaetae from III, each bundle with one or two short $(100-150 \mu \mathrm{m})$ hairs, each with two support chaetae. Ventral chaetae of XII absent in mature specimens, those of XIII (spermathecal chaetae) two pairs, each pair lying in a large glandular chaetal sac behind corresponding spermathecal vestibule; first chaeta large (110-130 $\mu \mathrm{m})$, deeply grooved distally, sharply pointed and projecting into vestibulae, second chaetae smaller, thinner and not projecting from sac (fig. 1D-F). Spermathecal chaetae absent in some mature specimens.

Dorsal muscular pharyngeal pad in II-III, with pharyngeal glands attached to either side of septa $3 / 4$ to $5 / 6$. Oesophagus in IV-IX, folded once in each segment and lined with ciliated cells. Gut widening in X, thereafter lining tissue folded and lacking cilia.

All genital pores ventral and paired. Male pores posteriorly on XII in line with ventral chaetae. Spermathecal vestibulae opening anteriorly on XIII in line with male pores, female pores on anterior wall of opening of spermathecal vestibulae (fig. 1E, F). Spermathecal vestibulae with wide openings connected by a shallow transverse depression of body wall.

Testes antero-ventral in XI (fig. 1E), with developing sperm present as far anterior as IV. Ovaries in XII, stringing out into XIII or even XIV, probably due to atria occupying much of XII, with egg sacs present in XIII-XV. Sperm funnels antero-ventral on $11 / 12$ with vasa deferentia highly coiled anteriorly in XII (fig. 1E). Union of atria and vasa deferentia not seen, but in sectioned worms, vas clearly seen near penis sacs so union presumably near where atria narrow before joining the penes. Unciliated atria long and tightly folded, occupying a large proportion of XII, with thin muscle layer, narrow lumen and thick unciliated lining tissue. The latter consisting of tall, flat cells, most of which are not in close contact with neighbouring cells, lending a loose appearance to the tissue (fig. $1 \mathrm{G}, \mathrm{H}$ ), but see remarks below. Penes tall, in muscular sacs that are almost as tall as the segment. Female funnels leading to pores on anterior face of the spermathecal vestibulae, near their wide openings (fig. 1F). Spermathecal vestibulae tall and muscular with muscular attachments to dorso-lateral body wall (fig. 1E). Spermathecal ducts leading from posterior of the slightly bulbous dorsal portion of vestibulae, travelling ventrally, then posteriorly to spermathecal ampullae which cover two or more segments from XIV or XV. Ampullae narrow and elongate anteriorly, becoming bulbous posteriorly. Sperm loose in ampullae, including its narrow anterior portion.

\section{Remarks}

This species is placed within Astacopsidrilus because of the tall muscular spermathecal vestibulae with female pores located within the openings of these, as per the above diagnosis. Astacopsidrilus plumaseta (Brinkhurst \& Fulton 1979), also from southeastern Tasmania and $A$. beckettae Pinder \& Brinkhurst 1997, from Subantarctic Campbell Island, are the only other Astacopsidrilus to have modified spermathecal chaetae. However, the brush-tipped dorsal chaetae of $A$. plumaseta are absent in the new species, while A. beckettae possesses more distinctly bifid ventral chaetae, and narrower, less tightly folded atria with more uniform lining tissue, than those of the new species. The cells of the atrial lining tissue of $A$. ostiensis are distinct and appear separated from each other (fig. $1 \mathrm{G}, \mathrm{H}$ ), as in the Tasmanian A. myothyros Pinder \& Brinkhurst 1997. Although it cannot be ruled out that the appearance of the $A$. ostiensis atrial lining tissue is an artifact of preservation or processing, most other phreodrilids, which have tightly packed atrial cells giving a more homogeneous appearance (Pinder \& Brinkhurst 1997: frg. 107) have generally been treated in the same way. Compared to $A$. myothyros, the penes of $A$. ostiensis are more elongate, and the atrial muscle layer is thinner. The chaetae of the two species also differ significantly. The ventral chaetae of $A$. myothyros have the upper tooth larger than the lower anteriorly and are simple-pointed posteriorly.

In the key to Australian phreodrilids of Pinder \& Brinkhurst (1997), A. ostiensis would key to couplet 17, where it would be separated from either of the options because of the rudimentary upper teeth on anterior ventral chaetae, and the discrete cells projecting into the atrial lumen, rather than atria with a dense layer of atrial lining cells.

The type specimens were collected from fine sand at lowwater mark in water with $4.7 \mathrm{ppt}$ salinity. This salinity is unlikely to be greatly exceeded at other times of the year (G. Edgar, pers. comm.).

\section{Other Worms}

A specimen collected from the Huon River, near Cradoc, southeastern Tasmania, on 5 November 1997, has chaetae similar to those of $A$. ostiensis, except that the upper teeth of the ventral chaetae are more obvious. The atria of this specimen have more evenly distributed, tightly packed lining tissue than $A$. ostiensis, are less tightly folded and lead, via narrow ejaculatory ducts, to a pair of small sacs which may contain small penes. The spermathecal ducts lead to simple ventral pores, i.e. without vestibulae. This worm was collected at low-water mark in water of 4.3 ppt salinity. Another individual, with similar chaetae but with genitalia that were difficult to observe, was collected at the same site on 16 May 1997 in water of $7.4 \mathrm{ppt}$.

A specimen from Blythe River, north coast of Tasmania, collected 16 January 1997, has similar chaetae to the Huon 
River material; it also has simple ventral spermathecal pores but has larger penes. Details of the atria are not visible from the single whole-mounted specimen. This specimen was collected at low-water mark in water of 14 ppt salinity.

Based on the genitalia, these other phreodrilids appear similar to species currently placed in the genus Insulodrilus or Nesodrilus, but identifications or descriptions will have to await the examination of further specimens.

\section{DISCUSSION}

As mentioned above, tall, muscular spermathecal vestibulae with openings associated with the female pores are considered diagnostic of the genus Astacopsidrilus (Pinder \& Brinkhurst 1997). Insulodrilus tanganyikae (Brinkhurst 1970) also has tall, muscular spermathecal vestibulae, but its female pores are well anterior to these (Brinkhurst 1970: fig. 1A, confirmed by P. Martin, pers. comm.), possibly within the intersegmental furrow or only just behind septum 12/13, although penetration of the septum can be difficult to detect. Insulodrilus litoralis, which has small vestibulae, has female pores in a similar position (Michaelsen 1924: fig. 1). Some other Insulodrilus, such as $I$. nudus (Brinkhurst \& Fulton 1979), have female ducts that are clearly plesioporous and lead to pores located between $12 / 13$ and the openings of the spermathecal vestibulae (Pinder \& Brinkhurst 1997: fig. 86), but all of these have vestibulae that are shorter and less muscular. Within Astacopsidrilus, some (such as $A$. myothyros) have female pores deep within the spermathecal vestibulae, while others (such as $A$. beckettae) have the female pores just coincident with the vestibulae openings. Thus, there is a continuity in the position of the female pores, such that it sometimes becomes difficult to state whether or not the female pores are separate from, or within, the vestibulae. With the new species, the openings of the vestibulae are so wide and so anterior that it is hard to imagine the female ducts penetrating $12 / 13$ and not appearing to be within the vestibulae. Female pores that are coincident with, or lying within, the vestibulae are probably a result of the extent of development of the latter, which leavelittle room for separate female pores. Insulodrilus tanganyikae is the exception here, although the illustration of this in Brinkhurst (1970) shows the vestibulae to be quite thin-walled ventrally. I. tanganyikae possibly belongs within Astacopsidrilus because of its tall vestibulae that are clearly very muscular dorsally. This would lead to a lesser emphasis on the position of Astacopsidrilus female pores, the location of which would merely be seen as a secondary result of the development of the vestibulae. The highly developed vestibulae would then become the principal synapomorphy uniting the species of Astacopsidrilus.

Of the 55 Tasmanian estuary sites sampled by Graham Edgar and Neville Barrett, oligochaetes were identified from only 36 , and phreodrilids occurred at only three of these. These three sites had salinities less than half seawater (4.3-14 ppt), whereas many tubificids and enchyrraeids were collected at sites with fully marine conditions (salinity about $35 \mathrm{ppt}$ ). This, and the similarity of $A$. ostiensis to several of the freshwater Tasmanian Astacopsidrilus, suggest that the new phreodrilids are derived from limnic forms and are probably restricted to the low salinity parts of estuaries.

\section{ACKNOWLEDGEMENTS}

We are indebted to Graham Edgar for providing the specimens. The Queen Victoria Museum's Plomley Foundation provided funding for histological work, which was carried out by Gordon Thomson of the School of Biological Sciences and Biotechnology, Murdoch University. The whole-mounted worms were prepared by Barbro Löfnertz of the Department of Zoology, University of Göteborg, Sweden. Emilia Rota (Universiti di Siena, Italy) kindly provided etymological advice. This work was part of a larger project which has been supported by the Australian Biological Resources Study. CE was funded by the Swedish Natural Science Research Council.

\section{REFERENCES}

Beddard, F.E., 1894: Preliminary notice of South American Tubificidae collected by Dr Michaelson, including the description of a branchiate form. Ann. Mag. Nat. Hist. 6: 205-210.

BenHam, W.B., 1909: Report on Oligochaeta of the Subantarctic Islands of New Zealand. In Chilton, C. (Ed.): THE SUBANTARCTICISLANDS OF NEWZEALAND. John Mackey, Wellington: 251-294.

BRINKHURST, R.O., 1966: A contribution towards a revision of the aquatic Oligochaeta of Africa. Zool. Afr. 2: 131-166.

BRINKHURST, R.O., 1970: A further contribution to towards a study of the aquatic Oligochaeta of Africa. Rev. Zool. Bot. Afr. 81: 101-108.

BRINKHURST, R.O., 1982: Additional aquatic Oligochaeta from Australia and New Zealand. Rec. Q. Vic. Mus. 78: 1-13.

Brinkmurst, R.O. \& Fulton, W., 1979: Some aquatic Oligochaeta from Tasmania. Rec. Q. Vic. Mus. 64: 1-13.

CoATES, K.A., 1990: Marine Enchytraeidae (Oligochaeta, Annelida) of the Albany area, Western Australia. In Wells, F.E., Walker, D.I., Kirkman H. \& Lethbridge, R. (Eds): PROCEEDINGS OF THE THIRD INTERNATIONAL MARINE BIOLOGICAL WORKSHOP: THE MARINE FLORA AND FAUNA OF ALBANY, WESTERN AUSTRALIA. VOL. I. Western Australian Museum, Perth: 13-41.

Edgar, G.J., Barrett, N.S. \& Graddon, D.J., 1998: A classification of Tasmanian estuaries and assessment of their conservation significance: An analysis using ecological and physical attributes, population and land use. Unpubl. rep. to Environ. Aust., Ocean Rescue 2000 - Marine Protected Areas Program.

Erséus, C., 1981: Taxonomic studies of Phallodrilinae (Oligochaeta, Tubificidae) from the Great Barrier Reef and the Comoro Islands, with descriptions of ten new species and one new genus. Zool. Scripta 10: 15-31.

ERSÉ, C., 1990a: Marine Tubificidae (Oligochaeta) of Victoria, Australia, with descriptions of six new species. Mem. Mus. Vic. 50: 275-285.

Ersévs, C., 1990b: The marine Tubificidae and Naididae (Oligochaeta) of South-Western Australia. In Wells, F.E., Walker, D.I., Kirkman H. \& Lethbridge, R. (Eds): PROCEEDINGS OF THE THIRD INTERNATIONAL MARINE BIOLOGICAL WORKSHOP: THE MARINE FLORA AND FAUNA OF ALBANY, WESTERN AUSTRALIA. VOL. 1. Western Australian Museum, Perth: 43-88.

Erseus, C., 1993: The marine Tubificidae (Oligochaeta) of Rottnest Island, Western Australia. In Wells, F.E., Walker, D.I., Kirkman H. \& Lethbridge, R. (Eds): PROCEEDINGS OF THE FIFTH INTERNATIONAL MARINE BIOLOGICAL WORKSHOP: THE MARINE FLORA 
AND FAUNA OF ROTTNEST ISLAND, WESTERN AUSTRALIA. Western Australian Museum, Perth: 331390.

ERSÉUS, C., 1997a: The marine Tubificidae (Oligochaeta) of Darwin Harbour, Northern Territory, Australia, with descriptions of fifteen new species. In Hanley, R.H., Caswell, G., Megirian, D. \& Larson, H.K. (Eds); PROCEEDINGS OF THE SIXTH INTERNATIONAL MARINE BIOLOGICAL WORKSHOP. THE MARINE FLORA AND FAUNA OF DARWIN HARBOUR, NORTHERN TERRITORY, AUSTRALIA. Museums and Art Galleries of the Northern Territory and the Australian Marine Sciences Association, Darwin: 99-132.

Erséus, C., 1997b: Marine Tubificidae (Oligochaeta) from the Montebello and Houtman Abrolhos Islands, Western Australia, with descriptions of twenty-three new species. In Wells, F.E. (Ed.): THE MARINE FLORA AND FAUNA OF THE HOUTMAN ABROLHOS ISLANDS, WESTERN AUSTRALIA. VOL. 2. Western Australian Museum, Perth: 389-458.

Erséus, C. \& Jamieson, B.G.M., 1981: Two new genera of marine Tubificidae (Oligochaeta) from Australia's Great Barrier Reef. Zool. Scr. 10: 105-110.

Giant, N., Martin, P. \& Juget, J., 1995: A new species of Phreodrilidae (Oligochaeta), Astacoposidrilus naceri $\mathrm{sp}$ nov, from Morocco (North Africa), with notes on the biogeography of the family. Can. J. Zool. 73: 23752381.

Goddard, E.J. \& Malan, D.E., 1913: Contributions to a knowledge of South African Oligochaeta. Part II. Descriptions of a new species of Phreodrilus. Trans. $R$. Soc. S. Afr. 3: 242-248.

Healy, B. \& CoAtes, K.A., 1997: Enchytraeids (Oligochaeta: Annelida) of the mid and upper intertidal of Darwin
Harbour, Northern Territory, Australia. In Hanley, R.H., Caswell, G., Megirian, D. \& Larson, H.K. (Eds): PROCEEDINGS OF THE SIXTH INTERNATIONAL MARINE BIOLOGICAL WORKSHOP. THE MARINE FLORA AND FAUNA OF DARWIN HARBOUR, NORTHERN TERRITORY, AUSTRALIA. Museums and Art Galleries of the Northern Territory and the Australian Marine Sciences Association, Darwin: 81-97.

JAMIESON, B.G.M., 1977: Marine meiobenthic Oligochaeta from Heron and Wistari Reefs (Great Barrier Reef) of the genera Clitellio, Limnodriloides, and Phallodrilus (Tubificidae) and Grania (Enchytraeidae). Zool. J. Linn. Soc. 61: 329-349.

Marchant, R. \& Lillywhite, P., 1994: A survey of the stream invertebrate communities on Macquarie Island. Aust. J. Mar. Freshw. Res. 45: 471-481.

Martin, P. \& BrinkHurst, R.O., 1994: A new species of Insulodrilus (Oligochaeta, Phreodrilidae) from Lake Tanganyika (East Africa) with notes on the oligochaete fauna of the lake. Arch. Hydrobiol. 130: 249-256.

Martin, P. \& Gian, N., 1995: Insulodrilus martensi, a new species of Phreodrilidae (Oligochaeta) from lake Tanganyika (East Africa). Ann. Limnol. 31: 3-8.

Michafison, W., 1900: Oligochaeta. Das Tierreich 10: 1-565. Michaelson, W., 1924: Oligochaeten von Neuseeland und den Auckland-Campbell Inseln, einigen anderen Pacifischen Formen. Vidensk. Medd. Dan. Naturhist. Foren. 75: 197240 .

Pinder, A.M. \& Brinkhurst, R.O., 1997: A review of the Phreodrilidae (Annelida: Oligochacta: Tubificida) of Australia. Invert. Tax. 11:443-523.

(accepted 17 May 2000) 